\title{
The quality of buck semen after feed additive minoxvit administration
}

\author{
Anita Hafid *, Riasari Gail Sianturi, Diana Andrianita Kusumaningrum, Yeni Widiawati, \\ Anneke Anggraeni, Ferdy Saputra \\ Indonesian Research Institute for Animal Production, PO BOX 221 Bogor 16002 \\ *Correspondence: anitahafid1@gmail.com
}

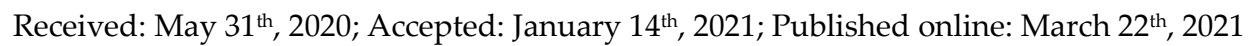

Abstrak

Tujuan: Hubungan antara reproduksi dengan status nutrisi sangat erat kaitannya. Kekurangan nutrisi atau asupan nutrisi yang tidak cukup dapat berpengaruh langsung terhadap efisiensi reproduksi termasuk penurunan kualitas sperma sehingga dapat berdampak pada kemampuan memfertilisasi. Penelitian ini bertujuan untuk menguji efek pemberian pakan aditif (Minoxvit) terhadap kualitas semen kambing.

Metode: Penelitian ini menggunakan 6 ekor kambing jantan berusia 1,5 tahun. Ternak diberikan pakan setiap harinya berupa rumput sebanyak $3 \mathrm{~kg}$, leguminosa (kaliandra) $1 \mathrm{~kg}$, serta konsentrat 500 g. Sejumah 3 ekor kambing diberi perlakuan berupa pemberian Minoxvit 1,25 g setiap hari yang dicampurkan pada konsentrat, sedangkan 3 ekor kambing lainnya sebagai kontrol. Minoxvit merupakan antioksidan alami yang diperoleh dari proses ekstraksi kulit buah Garcinia mangostana L yang diperkaya dengan bahan vitamin E dan mineral selenium. Evaluasi semen dilakukan sekali seminggu selama 49 hari meliputi pengamatan makroskopis dan mikroskopis. Evaluasi secara makroskopis meliputi warna, konsistensi, dan volume, sedangkan evaluasi secara mikroskopis meliputi gerakan massa, motilitas individu, viabilitas, dan konsentrasi spermatozoa. Data dianalisa menggunakan uji Tukey.

Hasil: Hasil penelitian menunjukkan adanya perbedaan yang signifikan $(P<0,05)$ dimana semen kambing yang diberi Minoxvit lebih baik dibandingkan semen tanpa pemberian Minoxvit, baik dari volume semen $(0,75 \mathrm{ml}$ vs $0,54 \mathrm{ml})$, gerakan massa spermatozoa (3,32 vs 2,67), motilitas individu spermatozoa (70\% vs 58\%), viabilitas spermatozoa $(86,67 \%$ vs $79,19 \%)$, maupun konsentrasi spermatozoa $\left(2,6 \times 10^{9} \mathrm{~mL}\right.$ vs $\left.1,7 \times 10^{9} \mathrm{~mL}\right)$.

Kesimpulan: Kesimpulan dari penelitian ini yaitu Minoxvit dapat meningkatkan kualitas semen kambing baik dari volume, gerakan massa, motilitas individu, viabilitas maupun konsentrasi spermatozoa.

Kata Kunci: Pakan aditif; Minoxvit; Kualitas semen; Kambing

\section{Abstract}

Objective: Reproduction and nutritional status is closely related. Nutritional deficiency or insufficiency directly affects reproductive efficiency. Deficiency of nutrition could affect the sperm quality and the ability to fertilize. The objective of this study was to evaluate the effect of feed additive (Minoxvit) on semen quality of buck. 
Methods: This study used 6 sexually mature bucks, aged 1.5 years old. The bucks were fed daily with $3 \mathrm{~kg}$ of freshly chopped king grass, $1 \mathrm{~kg}$ of Legume (Calliandra sp.), and $500 \mathrm{~g}$ of concentrate. Three bucks were given Minoxvit by $1.25 \mathrm{~g} /$ day in the concentrate, while three other bucks were considered as control. Semen was evaluated once a week for 49 days. Semen was evaluated macroscopically and microscopically. The macroscopic evaluation consisted of volume, color, and consistency of semen, while microscopic evaluation consisted of mass motility, sperm motility, viability, and sperm concentration. Data were analyzed using Completely Randomized Design with Tukey test.

Results: The result showed significantly different $(P<0,05)$ in which bucks semen in Minoxvit addition group had higher semen volume $(0.75 \mathrm{ml}$ vs $0.54 \mathrm{ml})$, mass motility (3.32 vs 2.67), sperm motility $(70 \%$ vs $58 \%$ ), sperm viability $(86.67 \%$ vs $79.19 \%)$, and sperm consentration $\left(2,6 \times 10^{9} \mathrm{~mL}\right.$ vs $\left.1,7 \times 10^{9} \mathrm{~mL}\right)$.

Conclusions: This study concludes that the addition of Minoxvit has a positive influence on the quality of buck sperms providing volume, mass motility, individual motility, viability, and concentration of the sperm.

Keywords: Feed additive; Minoxvit; Semen quality; Buck

\section{INTRODUCTION}

One of the factors related to low goat population is the lack of reproductive management efficiency. The low reproductive efficiency indicates reproductive disruptions [1]. Reproduction and nutritional status is closely related. Nutritional deficiency or insufficiency directly affects reproductive efficiencies, such as low reproductive performance and productivity [2].

Some research showed that the damage of the cell membrane was as the main factor affecting the damage of spermatozoa motility [3]. Reactive Oxygen Species (ROS) are compounds that are naturally produced in cellular metabolism which are very easy to attack spermatozoa cell membranes. Spermatozoa and semen plasma have endogenous enzymatic and non-enzymatic defenses that can ward off ROS [4], but the excessive and unbalanced ROS production will weaken the antioxidant enzymatic defense system, causing oxidative stress. Oxidative stress on spermatozoa disrupts the stability of the spermatozoa plasma membrane [5] which ultimately reduces spermatozoa motility [6].

The formation of lipid peroxide can be suppressed by the antioxidants [7]. Previous research by Jung et al [8] reported that mangosteen (Garcinia mangostana L.) was suspected to has potency as an antioxidant which was able to make testis free from radicals. Besides, vitamin E can also be a good reducing agent as an antioxidant to repair the cell membrane from the reaction of oxidation by protecting the structure and function of cells. Research conducted by Yue et al [9] indicates that supplementation of vitamin $\mathrm{E}$ improved semen quality in Jintang black sheep and Aohan fine-wool sheep. Beside antioxidants, there was selenium mineral, reported by Jacyno et al [10], that improve quality of spermatozoa.

Minoxvit is a natural antioxidant obtained from the extraction process of Garcinia mangostana $L$ peel enrich with vitamin $\mathrm{E}$ and selenium mineral so that it helps in overcoming the problem of low quality semen due to the stress caused by free radicals. Therefore, this study was conducted to evaluate the effect of Minoxvit on semen quality of buck.

\section{MATERIALS AND METHODS}

\section{Animal}

This research was conducted in the small ruminant pen, Indonesian Research Institute for Animal Production, Ciawi. The materials used in this study were 6 bucks. All buck aged 1.5 years, with an average body weight of $31.5 \pm 3.61 \mathrm{~kg}$. Semen evaluation was carried out once a week for 49 days, depending on the length of the spermatogenesis [11]. Each buck was individually caged $90 \mathrm{~cm} \times 90 \mathrm{~cm}$. The bucks were divided into two groups of 
treatment: three bucks with Minoxvit $1.25 \mathrm{~g}$ administration and another three as control.

\section{Feeding Procedure}

The bucks in the treatment group fed with basal diet consisted of freshly chopped king grass (Pennisetum purpuroides) as much as $3 \mathrm{~kg}, 1 \mathrm{~kg}$ of fresh calliandra, and $500 \mathrm{~g}$ concentrate mixed with $1.25 \mathrm{~g}$ of Minoxvit. The Minoxvit ingredient used in this study contained of a mixture of Garcinia mangostana $L$ peel extract, vitamin $E$, and selenium mineral. The three compositions of Minoxvit then homogenized and weighed as much as $1.25 \mathrm{~g}$ per dose to be given to the treated bucks [12]. Minoxvit was given for 49 days. Feed intake was determined by calculating the amount of feed consumed by the animals (feed intake $(\mathrm{kg})=$ offered feed $(\mathrm{kg})$ - feed residue on the next day $(\mathrm{kg})$. The bucks in control group were fed every day based on basal diet consisting of freshly chopped king grass (Pennisetum purpuroides) as much as $3 \mathrm{~kg}, 1 \mathrm{~kg}$ of fresh calliandra, and $500 \mathrm{~g}$ concentrate.

\section{Semen Collection Procedure}

The semen collection procedure was carried out according to Arifiantini [13]. Buck semen was collected using an artificial vagina once a week in the morning. The artificial vagina was prepared by installing both a rubber sheath (inner liner) and a sterile container. The water inserted to the $\mathrm{AV}$ had to be $50^{\circ} \mathrm{C}$, the final temperature is $40-45^{\circ} \mathrm{C}$. The artificial vagina smeared with lubricating jelly was carried by a semen collector using a right hand.

A buck came closer to the teaser then allowed to ride an other buck approximately three times to provoke its libido. Furthermore, when the male mounting the fourth time, the fresh semen was collected using an artificial vagina prepared and immediately evaluated macroscopically and microscopically.

\section{Fresh Semen Evaluation Procedure}

Fresh semen evaluation procedure was carried out according to Arifiantini [13]. The process of evaluating semen had to be precisely done to avoid and minimize the spermatozoa damage, death, and energy lost.
Semen was evaluated macroscopically and microscopically. The macroscopic evaluation included of color, consistency, and volume of semen, whereas microscopic evaluation included of mass movement, individual motility, viability, and concentration of sperm.

The volume of semen was assessed by looking at the scale on a scale container tube. The average volume of buck semen was 0.5-2 ml. Consistency or viscosity degree was assessed based on the speed of semen returning to the bottom of the container, with a liquid, medium, and viscous category. Normal semen color can be muddy white, milky white, beige, yellowish beige to grayishwhite color.

Microscopic semen observation was conducted by checking the motility of the sperm mass movement. Preparations for mass movement or mass motility was conducted by placing one drop of semen on a clean glass object, the droplet of semen should not be too convex so that the sperm would be looked clearly. The observation was conducted under a microscope with a magnification of $10 \times 10$ (100 times). The assessment was handled by 1) looking at the thickness of the spermatozoa mass and 2) the speed of the spermatozoa wave moving. The evaluation criteria were: + to +++++ depending on mass thickness wave and speed of movement. Individual motility could be observed by mixing semen with physiological $\mathrm{NaCl}$. One small drop of the mixed solution was taken and covered with a glass cover then observed under a microscope with a magnification of 400 times. The assessment was carried out with a minimum of 5 fields of view. Viability was held by making preparation contains eosin nigrosin dye then observed under a microscope with 400 times magnification. The spermatozoa concentration assessment used a counting chamber (Neubauer chamber). Semen was first diluted with formalin $\mathrm{NaCl}$ in the ratio of $2,5 \mu \mathrm{l}$ semen mixed with $1000 \mu \mathrm{l}$ of formalin $\mathrm{NaCl}$ which was then observed under a microscope with 400 times magnification.

\section{Statistical Analysis}

The effect of Minoxvit on Mass Motility, Individual Motility (\%), Viability (\%), 
Concentration (million / mL) was analyzed using a Completely Randomized Design with Tukey test. The model used was as follows:

$$
Y_{i j}=\mu+T_{i}+\varepsilon_{i j}
$$

where $Y_{i j}$ was an observation, $\mu$ was population mean, $T_{i}$ was the effect of Minoxvit, and $\varepsilon_{\text {ij }}$ was a residual error.

\section{RESULT}

\section{Feed Intake}

The feed consumed by each buck every day was legume (calliandra) with a dry matter (DM) weight of $460 \mathrm{~g}$ and concentrate with a $\mathrm{DM}$ of $460 \mathrm{~g}$. The freshly chopped king grass given as much as $3000 \mathrm{~g}$ per day was all consumed. The consumption of DM feed by each buck during the research periods (Table 1). All the bucks, both in control and treatment groups, consumed similar amount of dry matter, which also indicated the same amount of protein consumption. This data also indicated that the differences in the quality of sperm from each buck between the two treatment groups were caused by the addition of feed additive Minoxvit.

\section{Macroscopic Semen from Different of Buck Given and without Minoxvit}

The results of the macroscopic observations showed a significant difference in bucks added with Minoxvit with an average volume of semen of $0.75 \pm 0.29 \mathrm{~mL}$ higher than the average volume $0.54 \pm 0.35 \mathrm{~mL}$ of buck semen without the Minoxvit. Bucks given with Minoxvit demonstrated semen volume higher $(\mathrm{P}<0.05)$ than those without Minoxvit (Table 2).

As for the observations of the color and consistency, there were differences in the sperm composition of the bucks added with Minoxvit, namely cream-colored semen with viscous consistency, whereas semen from the bucks not added with Minoxvit was creamy-yellow with liquid consistency (Table 2). The consistency and color of semen affected the amount of spermatozoa concentration. As in buck semen added by Minoxvit, it appears cream-colored with viscous consistency compared to semen from control group that appears yellowish beige with a liquid consistency.

\section{Microscopic Evaluation of Spermatozoa}

Microscopic observations showed significant differences $(P<0,05)$ between the buck given with and without Minoxvit providing mass motility 3.32 vs 2.67 , individual motility $70 \%$ vs $58 \%$, viability $86.67 \%$ vs $79.19 \%$, and spermatozoa's concentration $\left(2,6 \times 10^{9} \pm 0,8 \mathrm{~mL}\right.$ vs $1,7 \times 10^{9} \pm 0,4$ $\mathrm{mL}$ ) of sperm (Table 3).

\section{DISCUSSION}

Based on the result of this study, the semen quality of bucks fed with Minoxvit was better compared to those wtihout Minoxvit. The total concentration of spermatozoa added with Minoxvit was higher because this feed additive contains antioxidant and minerals, which are required for hormone reproduction production, namely testosterone. This hormone influences spermatozoa forming and maturation in seminiferous tubule. This condition can optimize the spermatogenesis process resulted in the increases of spermatozoa concentration[14, 15] and motility [16]. One of antioxidant function donate one of its electrons towards the oxidant compound so it blocks their activity [17]. These antioxidants complete the lack of electrons in the free radicals, further preventing the reaction from free radicals formation which can result in many damaged cells [18]. Chomnawang et al [19] also reported that the

Table 1. Consumption of DM feeds by each buck during the research periode

\begin{tabular}{lcc}
\hline \multicolumn{1}{c}{ Consumption of DM feed } & -Minoxvit & +Minoxvit \\
\hline Fresh chopped king grass (g/head/day) & $378.29 \pm 37.57$ & $372.00 \pm 22.89$ \\
Legume (Calliandra) (g/head/day) & $460.00 \pm 0.00$ & $460.00 \pm 0.00$ \\
Consentrate (g/head/day) & $460.00 \pm 0.00$ & $460.00 \pm 0.00$ \\
Total consumption of DM feed (g/head/day) & $1298.29 \pm 37.57$ & $1292.00 \pm 22.89$ \\
\hline
\end{tabular}


Table 2. Macroscopic Evaluation of Bucks Fresh Semen

\begin{tabular}{ccc}
\hline Semen characteristics & Treatment & Average \\
\hline Volume $(\mathrm{mL})$ & + Minoxvit & $0.75 \pm 0.29^{\mathrm{a}}$ \\
& - Minoxvit & $0.54 \pm 0.35^{\mathrm{b}}$ \\
Color & + Minoxvit & Cream \\
& - Minoxvit & Yellowish beige \\
Consistency & + Minoxvit & Viscous \\
& - Minoxvit & Liquid \\
\hline
\end{tabular}

Note: ${ }^{\mathrm{a}, \mathrm{b}}$ Different letter in the same column shows significantly different $(P<0.05)$

Table 3. Microscopic Evaluation of Bucks Fresh Semen

\begin{tabular}{ccccc}
\hline Treatment & Mass Motility & Individual Motility $(\%)$ & Viability (\%) & Consentration (billion/mL) \\
\hline +Minoxvit & $3.32 \pm 0.87^{\mathrm{a}}$ & $70 \pm 0.07^{\mathrm{a}}$ & $86.67 \pm 6.40^{\mathrm{a}}$ & $2,6 \pm 0,8^{\mathrm{a}}$ \\
-Minoxvit & $2.67 \pm 1.02^{\mathrm{b}}$ & $58 \pm 0.10^{\mathrm{b}}$ & $79.19 \pm 12.8^{\mathrm{b}}$ & $1.7 \pm 0,4^{\mathrm{b}}$ \\
\hline
\end{tabular}

Note: $\mathrm{a}, \mathrm{b}$ Different letter in the same column shows significantly different $(P<0.05)$.

ethanol extract of mangosteen peel has a significant antioxidant activity measured by blocking the free radical formation. This ethanol extract of mangosteen peel can inhibit $50 \%$ of radical formation and also reduces ROS production by blocking the radical superoxide $\left(\mathrm{O}^{2-}\right)$ and captures the radical hydroxyl $\left(\mathrm{OH}^{-}\right)$. Likewise, Ralebona [15] reported that Garcinia enhances sexual activity in normal male rats.

The three types of antioxidants found in Minoxvit improves the quality of spermatozoa because of the xanthone contained in the extract of Garcinia mangostana $L$ which can increase the hormone to optimize spermatogenesis. Other source of antioxidant such as vitamin $\mathrm{E}$ can improve spermatozoa concentration. Qu et al [20] stated the addition of vitamin $\mathrm{E}$ to the livestock has a positive effect to spermatozoa, the result shows that vitamin $\mathrm{E}$ regulates spermatogenesis to give a positive effect on the membranes of spermatozoa and to maintain cell presence and increase the concentration of spermatozoa. Mineral also can improve the sperm motility of young beef bulls Preedy et al [21]. Hong et al [22] also reported that through histological observation of testicular Boer goats supplemented with vitamin $\mathrm{E}$ can increases the number of germ cells such as Sertoli cells which are important for increasing spermatogenesis. Furthermore, Glade et al [23] reported that the synthesis of testosterone in Leydig cells is very sensitive to supplementation of vitamin E.
Vitamin E functions as an antioxidant chain breaker that captures free radicals in cell membranes and lipoprotein plasma reacted with lipid peroxide radicals formed by the oxidation of polyunsaturated fatty acids [24]. Vitamin E has essential fatty components for reproduction. It also has the ability as a high antioxidant to fight free radicals [25]. Previous research conducted by Qu et al [20] reported that vitamin E supplementation increased germinal cells amount in testis and epididymis.

Sperm quality also can be optimized by supplementing the selenium mineral. Selenium mineral can increase the amount of semen quality and reproductive hormone concentration. This is in line with Mojapelo \& Lehloenya [26] which reported in Saanen male goat. Selenium mineral is a cofactor component of the glutathione peroxidase enzyme system which is responsible for the extra and intracellular regulation of hydroperoxide [27]. Glutathione can be found in spermatozoa cells and semen plasma in concentrations of around $32,49 \pm 5,10 \mu \mathrm{M} / \mathrm{mL}$ in semen plasma [28]. Lovercamp et al [29] reported that supplementation of only selenium mineral does not have a significant effect on the quality of pig semen. However, it will improve the quality of spermatozoa if supplementation of organic selenium is added with vitamin E [10].

The increase of semen volume can be affect by testosterone hormone. In this research the semen volume has a significant different of bucks which was given Minoxvit 
compare with the bucks did not give Minoxvit. This can be caused by the increasing levels of testosterone hormone in bucks given Minoxvit which contain antioxidant. Antioxidants in Minoxvit consisted xanthone, vitamin E and selenium mineral. All this antioxidants increase the testosterone hormone production which influences spermatozoa forming and maturation in seminiferous tubule [15] and then the spermatozoa volume can be increased.

\section{CONCLUSION}

The addition of Minoxvit has a positive respons on the quality of buck sperm providing volume, mass motility, individual motility, viability, and concentration of spermatozoa.

\section{CONFLICT OF INTEREST}

The authors declare no real or perceived conflicts of interest.

\section{REFERENCES}

1. Amiridis, G. S., T. Tsiligianni, E. Dovolou, C. Rekkas, D. Vouzaras, and I. Menegatos. 2009. Combined administration of gonadotropin-releasing hormone, progesterone, and meloxicam is an effective treatment for the repeat-breeder cow. Theriogenology. 72:542-8. doi: 10.1016/j.theriogenology.2009.04.010.

2. Salem, M. B., M. Djemali, C. Kayouli, and A. Majdoub. 2006. A review of environmental and management factors affecting the reproductive performance of Holstein-Friesian dairy herds in Tunisia. Livest. Res. Rural Dev. 18.

3. Cosson, J. 2004. The ionic and osmotic factors controlling motility of fish spermatozoa. Aquac. Int. 12:69-85. doi: 10.1023/B:AQUI.0000017189.44263.bc.

4. Kankofer, M., G. Kolm, J. Aurich, and C. Aurich. 2005. Activity of glutathione peroxidase, superoxide dismutase and catalase and lipid peroxidation intensity in stallion semen during storage at $5^{\circ} \mathrm{C}$. Theriogenology. 63:1354-1365. doi:10.1016/ j.theriogenology.2004.07.005.
5. Tremellen, K. 2008. Oxidative stress and male infertility - A clinical perspective. Hum. Reprod. Update. 14:243-58. doi:10.1093/humupd/dmn004.

6. Michael, A. J., C. Alexopoulos, E. A. Pontiki, D. J. Hadjipavlou-Litina, P. Saratsis, H. N. Ververidis, and C. M. Boscos. 2009. Effect of antioxidant supplementation in semen extenders on semen quality and reactive oxygen species of chilled canine spermatozoa. Anim. Reprod. Sci. 112:119-35. doi:10.1016/ j.anireprosci.2008.04.007.

7. Iswanto, N., Suyadi, and A. Rachmawati. 2012. Pengaruh $\alpha$-tocopherol yang berbeda dalam pengencer dasar tris aminomethane-kuning telur terhadap kualitas semen kambing boer yang disimpan pada suhu 5oC. J. Ilmu-Ilmu Peternak. 22:1-8.

8. Jung, H. A., B. N. Su, W. J. Keller, R. G. Mehta, and A. D. Kinghorn. 2006. Antioxidant xanthones from the pericarp of Garcinia mangostana (Mangosteen). J. Agric. Food Chem. 54:2077-82. doi:10.1021/jf052649z.

9. Yue, D., L. Yan, H. Luo, X. Xu, and X. Jin. 2010. Effect of Vitamin E supplementation on semen quality and the testicular cell membranal and mitochondrial antioxidant abilities in Aohan fine-wool sheep. Anim. Reprod. Sci. 118:217-22. doi:10.1016/ j.anireprosci.2009.08.004.

10. Jacyno, E., M. Kawęcka, M. Kamyczek, A. Kołodziej, J. Owsianny, and B. Delikator. 2002. Influence of inorganic Se + vitamin $E$ and organic $\mathrm{Se}+$ vitamin $\mathrm{E}$ on reproductive performance of young boars. Agric. Food Sci. Finl. 11:175-184. doi:10.23986/afsci. 5723.

11. Senger, P. 2005. Pathways to Pregnancy and Parturition. 3rd ed. (P. Senger, editor.). Current Conceptions Inc.

12. Winugroho, M., Y. Widiawati, and T. Kostaman. 2014. Antioxidant as feed additive given to etawah grade bucks kept in different micro-climate environment (26oC vs $34 \mathrm{oC})$. In: Proceeding The 2nd Asia-Australasian Dairy Goat Conference. Bogor. p. 251- 253.

13. Arifiantini, R. 2012. Teknik Koleksi dan Evaluasi Semen pada Hewan. IPB Press, 
Bogor.

14. Permatasari FR, Marhendra APW, Aulanni'am. 2014. Studi Terapi Ekstrak Kulit Buah Manggis (Garcinia mangostana L.) terhadap Penurunan Kadar Malondialdehyde (MDA) pada Organ Testis dan Jumlah Spermatozoa Tikus (Rattus norvegicus) Hasil Induksi Paparan Asap Rokok. Malang: Program Studi Kedokteran Hewan Universitas Brawijaya.

15. Ralebona, N. 2012. Effects of ethanolic extract of Garcinia kola on sexual behaviour and sperm parameters in male Wistar rats. African J. Pharm. Pharmacol. 6:1077-1082. doi:10.5897/ajpp11.652.

16. Umar, S. H., E. de Queljoe, and L. Tendean. 2015. Pengaruh pemberian ekstrak kulit buah manggis (Garcinia mangostana 1.) terhadap kualitas spermatozoa wistar jantan (Rattus norvegicus) yang diberi paparan suhu panas. J. e-Biomedik. 3:670675. doi:10.35790/ebm.3.2.2015.9415.

17.Zarena, A. S., and K. U. Sankar. 2009. A study of antioxidant properties from Garcinia mangostana 1. pericarp extract. Acta Sci Pol Technol Aliment. 8:23-34.

18. Permatasari, F. R., A. P. W. Marhendra, and Aulanni'am. 2014. Studi terapi ekstrak kulit buah manggis (Garcinia mangostana L.) terhadap penurunan kadar malondialdehyde (MDA) pada organ testis dan jumlah spermatozoa tikus (rattus norvegicus) hasil induksi paparan asap rokok. Universitas Brawijaya.

19. Chomnawang, M. T., S. Surassmo, V. S. Nukoolkarn, and W. Gritsanapan. 2007. Effect of Garcinia mangostana on inflammation caused by Propionibacterium acnes. Fitoterapia. 78: 401-408. doi:10.1016/j.fitote.2007.02.019.

20. Qu, Y. H., L. Y. Jian, L. Ce, Y. Ma, C. C. Xu, Y. F. Gao, Z. Machaty, and H. L. Luo. 2019. Identification of candidate genes in regulation of spermatogenesis in sheep testis following dietary vitamin $\mathrm{E}$ supplementation. Anim. Reprod. Sci. 205:52-61. doi:10.1016/j.anireprosci.2019.04 .003 .
21. Preedy, G. W., S. L. Hill, J. S. Stevenson, R. L. Weaber, and K. C. Olson. 2018. Injectable trace-mineral supplementation improves sperm motility and morphology of young beef bulls. Prof. Anim. Sci. 34:1-9. doi:10.15232/pas.2017-01667.

22. Hong, Z., L. Hailing, M. Hui, and Z. Guijie. 2009. Effect of vitamin $E$ supplementation on development of reproductive organs in Boer goat. Anim. Reprod. Sci. 113:93-101. doi:10.1016/j.anireprosci.2008.05.076.

23. Glade, M. J., K. Smith, and M. M. Meguid. 2015. A glance at... nutritional antioxidants and testosterone secretion. Nutrition. 31:1295-8. doi:10.1016/j.nut.2015.05.019.

24. Murray, R. K., D. K. Granner, P. A. Mayes, and V. W. Rodwell. 2009. Biokimia Harper. 27th ed. Penerbit Buku Kedokteran (EGC), Jakarta.

25. Niki, E. 2014. Role of vitamin e as a lipidsoluble peroxyl radical scavenger: In vitro and in vivo evidence. Free Radic. Biol. Med. 66:3-12. doi:10.1016/j.freeradbiomed. 2013.03.022.

26. Mojapelo, M. M., and K. C. Lehloenya. 2019. Effect of selenium supplementation on attainment of puberty in Saanen male goat kids. Theriogenology. 138:9-15. doi:10.1016/j.theriogenology.2019.06.044.

27. Burk, R. F., and K. E. Hill. 1993. Regulation of selenoproteins. Annu. Rev. Nutr. 13:6581. doi:10.1146/annurev.nu.13.070193.0004 33.

28. Gadea, J., M. Molla, E. Selles, M. A. Marco, F. A. Garcia-Vazquez, and J. C. Gardon. 2011. Reduced glutathione content in human sperm is decreased after cryopreservation: Effect of the addition of reduced glutathione to the freezing and thawing extenders. Cryobiology. 62:40-6. doi:10.1016/j.cryobiol.2010.12.001.

29. Lovercamp, K. W., K. R. Stewart, X. Lin, and W. L. Flowers. 2013. Effect of dietary selenium on boar sperm quality. Anim. Reprod. Sci. 138:268-275. doi:10.1016/ j.anireprosci.2013.02.016. 